\title{
SOUR ORANGE BUD REGENERATION AND IN VITRO PLANT DEVELOPMENT RELATED TO CULTURE MEDIUM COMPOSITION AND EXPLANT TYPE ${ }^{1}$
}

\author{
ROSELY PEREIRA DA SILVA², AMANCIO JOSÉ DE SOUZA², \\ BEATRIZ MADALENA JANUZZI MENDES ${ }^{3}$, FRANCISCO DE ASSIS ALVES MOURÃO FILHO ${ }^{2}$
}

\begin{abstract}
In order to evaluate the formation of adventitious buds and in vitro regeneration of sour orange plants (Citrus aurantium L.) two organogenesis-inducing experiments were conducted. In the first experiment, the induction and in vitro regeneration of adventitious buds were tested on epicotyl and internodal segments under the influence of BAP or KIN associated with NAA. The second experiment evaluated the in vitro regeneration of sour orange plants related to different explant types (epicotyls segments, internodal segments of in vitro germinated plantlets and internodal segments of greenhouse cultivated plants). Data collected on both experiments included the percentage of responsive explants (explants that formed buds), and the number of buds per explant. The addition of BAP showed the best organogenic response. In vitro germinated epicotyl segments and internodal segments are recommended as explants for sour orange in vitro organogenesis. Rooting of regenerated shoots was achieved without the need of auxin in the medium.

Index terms: Citrus aurantium, organogenesis, epicotyl segment, internodal segment.

\section{REGENERAÇÃO DE GEMAS DE LARANJA-AZEDA E DESENVOLVIMENTO IN VITRO DE PLANTAS EM FUNÇÃO DA COMPOSIÇÃO DO MEIO DE CULTURA E TIPO DE EXPLANTE}

\begin{abstract}
RESUMO - Com o objetivo de avaliar a formação de gemas adventícias e regeneração in vitro de plantas de laranja-azeda (Citrus aurantium L.), foram realizados dois experimentos de indução à organogênese. No primeiro experimento, a indução e a regeneração in vitro de gemas adventícias foram investigadas a partir de segmentos internodais e segmentos de epicótilo sob o efeito de BAP ou CIN associados com ANA. O segundo experimento avaliou a regeneração in vitro de plantas de laranja-azeda em função do tipo de explante (segmentos de epicótilo, segmentos internodais de plantas germinadas in vitro e segmentos internodais de plantas cultivadas em casa de vegetação). Os dados coletados em ambos os experimentos incluíram a porcentagem de explantes responsivos (explantes que formaram gemas) e número de gemas por explante. A adição de BAP revelou a melhor resposta organogenética. Segmentos de epicótilo e segmentos internodais são explantes recomendados para a indução de organogênese in vitro de laranja-azeda. Enraizamento das brotações foi alcançado sem a adição de auxinas ao meio de cultura.
\end{abstract}

Termos para indexação: Citrus aurantium, organogênese, segmento de epicótilo, segmento internodal.

\section{INTRODUCTION}

In vitro plant regeneration can occur through organogenesis or somatic embryogenesis. Organogenesis can be defined as the process in which cells and tissues are induced to undergo changes leading to the formation of a unipolar structure. Organogenic events usually occur by cellular differentiation. Regaining of meristematic activity by the plant tissue characterizes two forms of organogenesis: direct and indirect. Organogenesis is characterized by the formation of adventitious buds. It is considered direct when bud regeneration occurs without callus, and defined as indirect when the regeneration process is preceded by callus formation, which develops into adventitious buds that grow into new organs (Phillips, 2004).

Sour orange (Citrus aurantium L.) has desirable characteristics when used as a rootstock (Castle et al., 1993), especially for sweet orange scion cultivars. However, its use has been severely limited due to its intolerance to the Citrus tristeza virus (CTV), which has caused one of the most important diseases of the citrus industry, leading to the destruction of millions of plants (Bar-Joseph \& Lee, 1989).

${ }^{1}$ (Trabalho 042-09). Recebido em: 10-02-2009. Aceito para publicação em: 27-06-2009.

2Universidade de São Paulo, Escola Superior de Agricultura “Luiz de Queiroz”, Av. Pádua Dias, 11, C. P. 9, 13418-900, Piracicaba-SP. roselyps@yahoo.com.br, amancio.souza@gmail.com. Autor correspondente: famourao@esalq.usp.br

${ }^{3}$ Universidade de São Paulo, Centro de Energia Nuclear na Agricultura, Av. Centenário, 303, C. P. 96, 13409-970, Piracicaba-SP. mendes@cena.usp.br 
Therefore, the development of CTV tolerant sour orange plants is desirable for citrus industry worldwide. One of the most likely successful approaches to produce this new cultivar is genetic transformation. On the other hand, the development of tissue culture protocols is important for developing transgenic sour orange plants tolerant to CTV. In vitro organogenesis has been obtained in several citrus cultivars by the cultivation of epicotyl and internodal segments in BAP supplemented culture medium (Ghorbel et al., 1998; Moura et al., 2001; Almeida et al., 2002, 2006; Silva et al., 2005a, 2005b; Schinor et al., 2006) or with BAP and NAA supplementation (Pérez-Molphe-Balch \& Ochoa-Alejo, 1997, Bordón et al., 2000; Moreira-Dias et al., 2000, 2001; Schinor, 2006). However, very little and inconsistent studies have been carried out specifically for sour orange.

This work objective was to evaluate the formation of adventitious buds and in vitro regeneration of sour orange plants through organogenesis.

\section{MATERIAL AND METHODS}

In vitro induction and regeneration of adventitious buds in sour orange epicotyl and internodal segments using two cytokine types (6-benzilaminopurine or kinetin) associated with naphthalene acetic acid.

Epicotyl segments used in this experiment were obtained from seeds extracted from mature sour orange (Citrus aurantium L.) fruits from plants at the Germplasm Bank of the "Centro APTA Citros Sylvio Moreira”, Cordeirópolis, Brazil. The seeds were washed and dried at room temperature for 24 hours. The integument was removed and the seeds were disinfected in 3:1 solution of water and sodium hypochlorite (2.5\% active chlorine) for 20 minutes under agitation. After disinfection, the seeds were washed three times in sterile distilled water under aseptic conditions. The seeds were then incubated in test tubes $(150 \times 25 \mathrm{~mm})$ containing $15 \mathrm{~mL}$ of MT (Murashige \& Tucker, 1969) culture medium supplemented with $2 \mathrm{~g} \mathrm{dm}^{-3}$ Phytagel ${ }^{\mathrm{TM}}$ and $25 \mathrm{~g}$ $\mathrm{dm}^{-3}$ sucrose, and $\mathrm{pH}$ adjusted to 5.8. Incubation was held at $27^{\circ} \mathrm{C}$ in the dark for $30 \mathrm{~d}$ in order to obtain elongated epicotyls. The plants were transferred to 16-h photoperiod for 10 to $15 \mathrm{~d}$, and then used as explant source. The explants consisted of epicotyl segments of $0.8-1.0 \mathrm{~cm}$ in length.

Internodal segments were obtained from juvenile shoots from two-year old plants, grown from sour orange seeds, cultivated in $35 \mathrm{~cm}$ x $20 \mathrm{~cm}$ plastic bags containing Rendmax Citrus ${ }^{\mathrm{TM}}$ potting mix, over $30 \mathrm{~cm}$ high benches, in greenhouse conditions (maxi- mum temperature of $37^{\circ} \mathrm{C}$, minimum of $18^{\circ} \mathrm{C}$ and air humidity of $60 \%$ ). These plants were constantly pruned, preserving the central branch, enabling the formation of new lateral shoots that were harvested for explant collection every 2 to 3 weeks. The disinfection of the internodal segments was conducted in 2:1 solution of water and sodium hypochlorite $(2.5 \%$ active chlorine) for 20 minutes. After disinfection, the internodal segments were washed three times in sterile distilled water under aseptic conditions. The segment length varied between $0.8-1.0 \mathrm{~cm}$.

Both explants (epicotyls and internodal segments) were placed on Petri dishes containing $20 \mathrm{~mL}$ of MT culture medium supplemented with BAP (1.0 $\mathrm{mg} \mathrm{dm}{ }^{-3}$ ) and NAA (0.3 $\left.\mathrm{mg} \mathrm{dm}^{-3}\right)$, or KIN (1.0 $\left.\mathrm{mg} \mathrm{dm}^{-3}\right)$ and NAA (0.3 $\mathrm{mg} \mathrm{dm}^{-3}$ ). The experimental design was totally randomized in a factorial format of $2 \mathrm{x}$ 2 (explant type $\mathrm{x}$ cytokinin type), with 5 replicates, each one consisting of a Petri dish with 20 explants. Incubation was conducted at $27^{\circ} \mathrm{C}$ in the dark for $30 \mathrm{~d}$, followed by $30 \mathrm{~d}$ at 16 -h photoperiod. After this period, the percentage of responsive explants as well as number of buds and/or shoots per responsive explant was evaluated.

In vitro induction and regeneration of adventitious buds and in vitro plant regeneration from different sour orange explants

This experiment evaluated different explant types of sour orange for adventitious bud induction. Root formation (percentage of rooted shoots) on different media composition was also recorded.

Different explant sources were used in this experiment: 1) Elongated epicotyl region of in vitro germinated plantlets (Epi E); 2) Short epicotyl of in vitro germinated plants (Epi S), short, due to germination in 16-h photoperiod; 3) Internodal segments of in vitro germinated plantlets, excluding the epicotyl region (IS in vitro); and 4) Internodal segments of juvenile plants cultivated in the greenhouse (IS gh). Epi E and IS gh explants were obtained as previously described in the first experiment. To obtain IS in vitro and Epi S explants, sour orange seeds were germinated under 16-h photoperiod. After 45 to 60 $\mathrm{d}$, these plants were used as explant source. The explants were $0.8-1.0 \mathrm{~cm}$ in length.

For the induction and development of the adventitious buds, the explants were cultivated in MT medium supplemented with $1.0 \mathrm{mg} \mathrm{dm}^{-3}$ BAP. Incubation was conducted at $27^{\circ} \mathrm{C}$ in the dark for $30 \mathrm{~d}$, followed by $30 \mathrm{~d}$ of 16 -h photoperiod. After this period, the percentage of responsive explants as well as number of buds and/or shoots per responsive explant was evaluated. The experimental design was 
totally randomized in with 8 replicates, each one consisting of a Petri dish with 20 explants.

Regenerated shoots were submitted to rooting. Shoots of approximately $1.0 \mathrm{~cm}$ in length were transferred to MT medium with half the salt concentration, supplemented with $500 \mathrm{mg} \mathrm{dm}^{-3}$ activated charcoal, $1.0 \mathrm{mg} \mathrm{dm}^{-3} \mathrm{IBA}, 1.0 \mathrm{mg} \mathrm{dm}^{-3} \mathrm{NAA}$, or with no auxin. This experiment was conducted with shoots from the Epi E, Epi S, and IS in vitro explants. Incubation was conducted at $27^{\circ} \mathrm{C}$ under 16 -h photoperiod. The experimental design was totally randomized in factorial format of $3 \times 3$ (explant origin $x$ culture medium), with 6 replicates, each one consisting of a Magenta ${ }^{\mathrm{TM}}$ container with 5 shoots. After 60 days of cultivation, the percentage of rooted shoots was evaluated.

\section{RESULTS}

In vitro induction and regeneration of adventitious buds in sour orange epicotyl and internodal segments using two cytokine types (6-benzilaminopurine or kinetin) associated with naphthalene acetic acid

Adventitious buds were observed in some explants as early as $15 \mathrm{~d}$ after cultivation. No interaction could be found between explant type and cytokinin type for the percentage of explants that developed buds and for the number of regenerated buds. The greatest percentage of responsive explants was obtained for epicotyl segments when BAP was used in the culture medium. The effect of the explant type was also significant, as the epicotyl segments showed the greatest average for the percentage of explants that formed buds (Table 1 ).

No differences were observed between explant types for the number of buds regenerated per responsive explant. However, the greatest average was registered when BAP was added in the medium (Table 1).

In vitro induction and regeneration of adventitious buds and in vitro plant regeneration from different sour orange explants

As previously observed in the first experiment, adventitious buds were formed as early as $15 \mathrm{~d}$ after cultivation, still under dark conditions. Different sour orange explant types were evaluated for in vitro regeneration response. The organogenic response as well as the conversion of buds into plants was recorded.

The highest percentage of responsive explant averages were obtained for the elongated epicotyl region of in vitro germinated plantlets (Epi E), internodal segments of in vitro germinated plantlets excluding the epicotyl region (IS in vitro), and short epicotyl of in vitro germinated plants (Epi S). The response of these explants (Epi S) was superior to the average of responsive explants from internodal segments of juvenile plants cultivated in the greenhouse (IS gh) (Table 2). Regarding the number of regenerated buds, the best responses were obtained for IS in vitro and Epi S, which induced the formation of 3.1 and 2.5 buds per explant, respectively. The IS gh explant had the lowest organogenic response.

There was a significant interaction between culture medium and explant origin on the percentage of shoots that produced roots, ranging from 48 to 88\% (Table 3). Shoots originated from explant Epi $E$ had greater percentages of rooting when cultivated in MT medium with half the salt concentration, and no auxin and on MT supplemented with $1.0 \mathrm{mg} \mathrm{dm}^{-3}$ de IBA when compared to MT with $1.0 \mathrm{mg} \mathrm{dm}^{-3}$ NAA.

\section{DISCUSSION}

The results found herein showed that epicotyl segments cultivated on medium supplemented with BAP are adequate to sour orange in vitro organogenesis. Previous research has described that the best organogenic response for sour orange explants was obtained in the presence of BAP in the culture medium (Silva et al., 2008). On the other hand, epicotyl segments are the recommended explant type for obtaining such a positive response to BAP, as expressed by the percentage of responsive explants. Other research works have shown the importance of BAP supplementation in the culture media, as this cytokinin assures a greater number of adventitious buds in in vitro cultivated citrus explants (MoreiraDias et al., 2001; Almeida et al., 2002; Silva et al., 2005a, 2005b; Schinor et al., 2006).

The addition of growth regulators to culture media supply the endogenous levels of hormones in explants that are separated from the plant hormone production sites. The explant response to growth regulator supplementation depends on the explant physiological state, which is related to when the explant is collected along the year (Altman \& Goren, 1977), and explant donor plant condition (nutritional and health states). It has been observed that BAP highly induces the formation of adventitious shoots, while KIN allows normal shoot growth (Hu \& Wang, 1983).

In vitro organogenesis of Troyer citrange (Citrus sinensis x Poncirus trifoliata) epicotyls cultivated on medium containing $1.0 \mathrm{mg} \mathrm{dm}^{-3}$ BAP and $0.1 \mathrm{mg} \mathrm{dm}^{-3}$ NAA revealed an average of 10.4 buds per explant, 7.2 of which developed into shoots 
(Moreira-Dias et al., 2000), values higher than those obtained in our work. Pérez-Molphe-Balch \& Ochoa-Alejo (1997) cultivated Mexican lime (Citrus aurantifolia) and Monica tangerine (Citrus reticulata) internodal segments on MS medium supplemented with $7.5 \mathrm{mg} \mathrm{dm}^{-3}$ BAP and $1.0 \mathrm{mg}$ $\mathrm{dm}^{-3}$ NAA, leading to 96 and $88 \%$ responsive explants as well as 7.8 and 5.1 buds per explant for these cultivars, respectively. These results differ from the ones shown in our experiments when using internodal segments as explants. It is possible that the different responses observed in that report were due to differences in the plant material and concentrations of BAP.

It is important to point out that internodal segments did also produce adequate adventitious bud in our study. Several other reports have evaluated the response of internodal segments to organogenesis. Schinor et al. (2006) cultivated epicotyl segments on medium with $1.0 \mathrm{mg} \mathrm{dm}^{-3} \mathrm{BAP}$ and found an average of 1.39 buds per explant. The greatest percentage of responsive explants for sour orange, Rangpur lime and Volkamer lemon were obtained in the absence of growth regulators. Since BAP supplementation reduced the number of responsive explants, BAP appeared to be unfavorable for sour orange epicotyl segment organogenesis (Schinor, 2006). The average values obtained differ from the ones found in our experiments were BAP supplementation was favorable to the formation of adventitious buds per explant. In a 'Hamlin' sweet orange genetic transformation study using Agrobacterium tumefaciens, Mendes et al. (2002) considered epicotyl segments from in vitro cultivated plantlets an adequate source of explants. These plantlets were cultivated in the dark for approximately two weeks and then exposed to 16 -h photoperiod from 1 to 3 weeks. This cultivation condition was the same as the one used in the present work.

The different responses to BAP might also be related to the plant material genotype (Almeida et al., 2002; Schinor et al., 2006), culture medium composition, factors related to the plant material (type and age of the explant) and to incubation conditions (explant position on the medium and luminosity) (Bordón et al., 2000; Moreira-Dias et al., 2000; Costa et al., 2004; Silva et al., 2005a). In this context, additional studies are necessary if the goal is to obtain success in plant regeneration.

For grapefruit, sour orange, and Citrus macropylla cultivated on culture medium supplemented with $1.0 \mathrm{mg} \mathrm{dm}^{-3}$ BAP, 4.1, 2.2, and 9.9 buds per explant (internodal segments from 12 month old plants) were found respectively (Ghorbel et al., 1998). These results observed for sour orange are similar to those found in our work (1.8 and 2.0 buds per explant).

Internodal segments of in vitro germinated plants of Rangpur lime were evaluated for organogenic induction in culture medium with different BAP concentrations. The supplementation of $2.5 \mathrm{mg} \mathrm{dm}^{-3}$ of this growth regulator to the medium generated the greatest number of responsive explants as well as the greatest number of adventitious shoots per explant (Moura et al., 2001). Considering the same type of explant, our research found $83.8 \%$ of responsive explants and 3.1 buds per explant for sour orange cultivated on MT medium supplemented with 1.0 $\mathrm{mg} \mathrm{dm}{ }^{-3}$ BAP. Better results were found for Mexican lime (C. aurantifolia Christm. Swing.) and mandarin (C. reticulata Blanco cv. Monica) using $7.5 \mathrm{mg} \mathrm{dm}^{-3}$ BAP and $1.0 \mathrm{mg} \mathrm{dm}^{-3}$ NAA (Pérez-Molphe-Balch \& Ochoa-Alejo, 1997), as previously mentioned.

The maximum induction of adventitious buds in 'Pineapple' orange (Citrus sinensis) and citron (Citrus medica) explants was obtained on MS medium with $3.0 \mathrm{mg} \mathrm{dm}^{-3} \mathrm{BAP}$, while for lime (Citrus aurantifolia) $1.0 \mathrm{mg} \mathrm{dm}^{-3}$ BAP showed better results in explants obtained from internodal segments of greenhouse cultivated plants (Duran-Vila \& Navarro, 1989).

The use of $2.0 \mathrm{mg} \mathrm{dm}^{-3}$ of BAP led to the best response in terms of the percentage of responsive explants from internodal segments of Rangpur lime and sour orange plants cultivated in the greenhouse. For Rangpur lime, $82 \%$ of the segments regenerated 1.9 buds per explant and for sour orange, $49 \%$ of the segments regenerated 1.6 buds per explant. It was also observed that in the absence of BAP sour orange explants did not regenerate buds (Schinor, 2006). When evaluating the combination of BAP and NAA in organogenesis of sour orange internodal segments, the best response was obtained on MT medium with $2.0 \mathrm{mg} \mathrm{dm}^{-3}$ BAP and $0.3 \mathrm{mg} \mathrm{dm}^{-3}$ NAA (52\% of responsive explants and 1.6 buds per explant), and on DBA3 medium with $2.0 \mathrm{mg} \mathrm{dm}^{-3}$ BAP and $0.5 \mathrm{mg}$ $\mathrm{dm}^{-3} \mathrm{NAA}$ (63\% of responsive explants and 2.2 buds per explant) (Schinor, 2006).

In a genetic transformation experiment with the objective of determining the incubation efficiency of internodal segments of Citrus aurantifolia Swing., it was observed that the explants cultivated on MS medium containing 1,0 $\mathrm{mg} \mathrm{dm}^{-3} \mathrm{BAP}$, maintained in the dark for 15 days and subsequently transferred to light conditions, had the best responses $(41.9 \%$ of responsive explants) (Peña et al., 1997). In the present work, all of the explants were incubated for 30 days in the dark, and then placed under 16 -h photoperiods 
for 30 days.

In our second experiment, epicotyl segments (Epi E) were explants favorable to organogenic induction on medium containing $1.0 \mathrm{mg} \mathrm{dm}^{-3} \mathrm{BAP}$, in which $76.3 \%$ of the segments regenerated 2.0 buds per explant, differing from the results obtained by Schinor et al. (2006) who found that only 39\% of regenerated segments with 1.4 buds per explant in sour orange.

The explant Epi S was studied in order to observe possible response differences between the Epi S region and the vertical axis of plantlets germinated in vitro. Since no differences were observed between Epi S and IS in vitro, in vitro germinated plants may have their full length used as explants. Therefore, this experiment revealed that the best sour orange explants for in vitro organogenesis are internodal segments of in vitro germinated plantlets and epicotyl segments from germination in the dark, followed by light incubation conditions. The shoots obtained from Epi E, Epi S and IS in vitro developed in a satisfactory manner and were induced for rooting in a different experiment. The insufficient response obtained for IS gh did not allow rooting evaluation from this explant.

Despite of the fact that micrografting techniques have been successful, with survival rates of 51, 60 and 94\% for grapefruit, sour orange and Citrus macrophylla Wester, respectively (Ghorbel et al., 1998), and $100 \%$ for 'Pera' sweet orange (Silva et al., 2005a), in vitro rooting has been evaluated in plant regeneration protocols.

The rooting rates found in our work are adequate when compared to previous studies: $80 \%$ for Pineapple orange (Citrus sinensis) (Duran-Vila et al., 1992), 84\% for Citrus macrophylla (Ghorbel et al., 1998), 70 \% for Mexican lime (Pérez-Molphe-Balch \& Ochoa-Alejo, 1997) and 86\% for Troyer citrange (Moreira-Dias et al., 2000).
Culture medium with half the salt concentration and no auxin assured the rooting of the shoots independent of the explant type. These shoots generated roots varying from 5.3 to $15 \mathrm{~cm}$ in length. This condition was essential for the successful plant adaptation to greenhouse conditions.

Rooting induction in citrus has been obtained by the use of culture medium with no growth regulators or auxin supplementation, and in medium with half the salt concentration (Bespalhok Filho et al., 2001; Moura et al., 2001; Almeida et al., 2002; Silva et al., 2005a, 2005b).

The absence of auxin also led to 58\% of rooted shoots obtained from epicotyl segments in 'Pera' sweet orange (Silva et al., 2005a), and 85\% in 'Cleopatra' mandarin (Silva et al., 2005b). For 'Troyer' citrange, $100 \%$ of rooted shoots were found when working with the same explant type on medium with $2.0 \mathrm{mg} \mathrm{dm}^{-3} \mathrm{NAA}$ (Edriss \& Burger, 1984).

Shoots obtained from internodal segments of in vitro germinated Rangpur lime plants cultivated on $1.0 \mathrm{mg} \mathrm{dm}^{-3}$ NAA showed $80 \%$ of rooting. This same NAA concentration favored root emission on 75 and $80 \%$ of 'Pera' and 'Valencia' sweet oranges shoots respectively, shoots originating from the epicotyl region (Moura et al., 2001). IBA utilization at $1.0 \mathrm{mg} \mathrm{dm}^{-3}$ induced an epicotyl segment rooting response of 75, 54, and 56\% on 'Natal', 'Valencia' and 'Pera' sweet oranges respectively, and an average of $94.6 \%$ for Rangpur lime (Almeida et al., 2002).

The results reported herein showed that the addition of BAP to the culture medium led to the best organogenic response. In vitro germinated epicotyl and internodal segments are two recommended explant types for in vitro organogenesis. No auxin is needed to root regenerated shoots. These adjustments in the protocol may facilitate in vitro sour orange plant regeneration. 
TABLE 1 -Percentage of responsive explants and buds and/or shoots per responsive explant regenerated in vitro from epicotyl segments (in vitro obtained) and internodal segments (greenhouse obtained) of sour orange related with the cytokinin type (BAP or KIN) in combination with NAA, 60 days after cultivation in MT culture medium (30 days in the dark, followed by 16-h photoperiod).

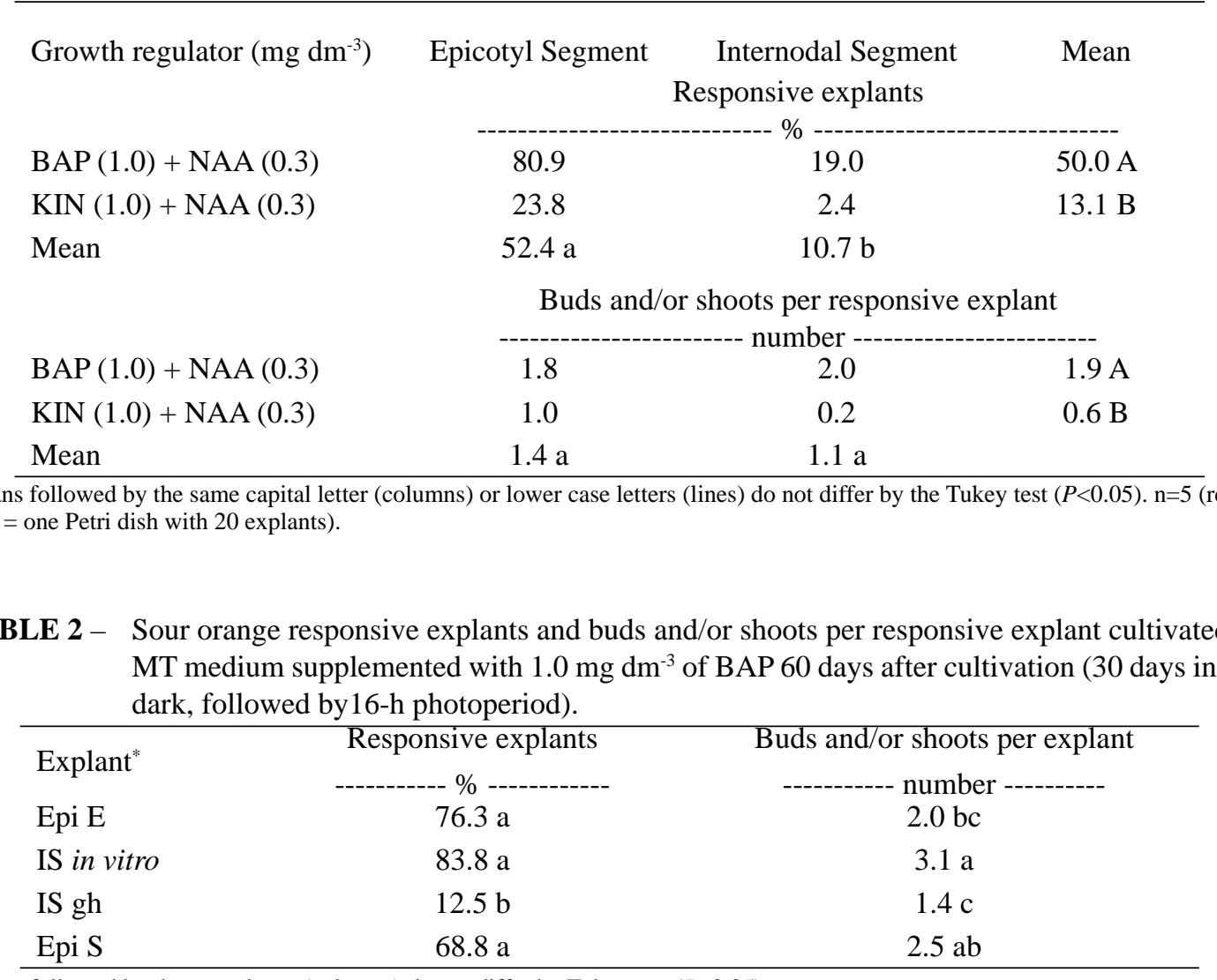

Means followed by the same letter (columns) do not differ by Tukey test $(P<0.05)$.

${ }^{*}$ Epi E (elongated epicotyl region of in vitro germinated plantlets), IS in vitro (internodal segments of in vitro germinated plantlets, excluding the epicotyl region), IS gh (internodal segments of juvenile plants cultivated in the greenhouse) and Epi S (short epicotyl of in vitro germinated plants)

$\mathrm{n}=8$ (replicate $=$ one Petri dish with 20 explants).

TABLE 3 - Rooting of sour orange shoots originated from different explants cultivated in MT medium with no growth regulator, with IBA supplementation or with NAA supplementation after 60 days cultivation under 16-h photoperiod.

\begin{tabular}{lccc}
\hline & \multicolumn{3}{c}{ Media for rooting induction } \\
\cline { 2 - 4 } Explant origin $^{*} \mathrm{MT}$ & $\mathrm{MT}+1.0 \mathrm{mg} \mathrm{dm}^{-3} \mathrm{IBA}$ & $\mathrm{MT}+1.0 \mathrm{mg} \mathrm{dm}^{-3} \mathrm{NAA}$ \\
\hline Epi E & $84 \mathrm{Aa}$ & $56 \mathrm{ABb}$ & $48 \mathrm{Bb}$ \\
IS in vitro & $80 \mathrm{Aa}$ & $64 \mathrm{Aab}$ & $88 \mathrm{Aa}$ \\
Epi S & $64 \mathrm{Aa}$ & $88 \mathrm{Aa}$ & $64 \mathrm{Aab}$ \\
\hline
\end{tabular}

Means followed by the same capital letter (lines) or lower case letters (columns) do not differ by the Tukey test $(P<0.05)$.

${ }^{*}$ Epi E (elongated epicotyl region of in vitro germinated plantlets), IS in vitro (internodal segments of in vitro germinated plantlets, excluding the epicotyl region) and Epi S (short epicotyl of in vitro germinated plants).

$\mathrm{n}=6$ (replicate $=5$ plants). 


\section{CONCLUSIONS}

1-The addition of BAP shows the best organogenic response.

2-In vitro germinated epicotyl segments and internodal segments are recommended as explants for sour orange in vitro organogenesis.

3-Rooting of regenerated shoots is achieved without the need for auxin in the medium.

\section{ACKNOWLEDGMENTS}

To Conselho Nacional de Desenvolvimento Científico e Tecnológico (CNPq) for the scholarship to the first author, and fellowship to the third and fourth author. To Fundo de Defesa da Citricultura (Fundecitrus) for financial support. To Dr. Jay Lee Schell for critical comments.

\section{REFERENCES}

ALMEIDA, W.A.B.; MOURÃO FILHO, F.A.A.; MENDES, B.M.J.; RODRIGUEZ, A.P.M. Histological characterization of in vitro adventitious organogenesis in Citrus sinensis. Biologia Plantarum, Copenhagen, v.50, p.321-325, 2006.

ALMEIDA, W.A.B.; MOURÃO FILHO, F.A.A.; MENDES, B.M.J.; RODRIGUEZ, A.P.M. In vitro organogenesis optimization and plantlet regeneration in Citrus sinensis and C. limonia. Scientia Agricola, Piracicaba, v.59, p.35-40, 2002.

ALTMAN, A.; GOREN, R. Horticultural and physiological aspects of Citrus bud culture. Acta Horticulturae, Leuven, v.78, p.51-60, 1977.

BAR-JOSEPH, M. R.; LEE, R.F. The continuous challenge of citrus tristeza virus control. Annual Review of Phytopathology, Palo Alto, v.27, p.291316, 1989.

BESPALHOK FILHO, J.C.; KOBAYASHI, A.K.; PEREIRA, L.F.P.; HISSANO, Z.; VIEIRA, L.G.E. In vitro adventitious shoot regeneration from sweet orange using thin epicotyl sections. Crop Breeding and Applied Biotechnology, Londrina, v.1, p.2734, 2001.
BORDÓN, Y.; GUARDIOLA, J.L.; GARCÍA-LUIS, A. Genotype affects the morphogenic response in vitro of epicotyl segments of Citrus rootstocks. Annals of Botany, Londres, v.86, p.159-166, 2000.

COSTA, M.G.C.; ALVES, V.S.; LANI, E.R.G.; MOSQUIM, P.R.; CARVALHO, C.R.; OTONI, W.C. Morphogenic gradients of adventitious bud and shoot regeneration in epicotyl explants of Citrus. Scientia Horticulturae, Amsterdam, v.100, p.63-74, 2004.

CASTLE, W.S.; TUCKER, D.P.H.; KREZDORN, A.H.; YOUTSEY, C.O. (Ed.). Rootstocks for Florida citrus. Gainesville: University of Florida, 1993. 92p.

DURAN-VILA, N.; GORGOCENA, Y.; ORTEGA, V.; ORTIZ, J.; NAVARRO, L. Morphogenesis and tissue culture of sweet orange (Citrus sinensis L. Osbeck): effect of temperature and photosynthetic radiation. Plant Cell, Tissue and Organ Culture, Dordrecht, v.29, p.11-18, 1992.

DURAN-VILA, N.; NAVARRO, L. Morphogenesis and tissue culture of three Citrus species. Plant Cell, Tissue and Organ Culture, Dordrecht, v.16, p.123-133, 1989.

EDRISS, M.H.; BURGER, D.W. In vitro propagation of 'Troyer' citrange from epicotyl segments. Scientia Horticulturae, Amsterdam, v.23, p.159-162, 1984.

GHORBEL, R.; NAVARRO, L.; DURAN-VILA, $\mathrm{N}$. Morphogenesis and regeneration of whole plants of grapefruit (Citrus paradisi), sour orange (C. aurantium) and alemow (C. macrophylla). Journal of Horticultural Science \& Biotechnology, Ashford, v.73, p.323-327, 1998.

HU, C.Y.; WANG, P.J. Meristem, shoot tip and bud cultures. - In: EVANS, D.A., SHARP, W.R., AMMIRATO, P.V.; YAMADA, Y. (Ed.). Handbook of plant cell culture. New York: Macmillan, 1983. p.177-227..

MENDES, B.M.J.; BOSCARIOL, R.L.; MOURÃO FILHO, F.A.A.; ALMEIDA, W.A.B. Agrobacteriummediated genetic transformation of 'Hamlin' sweet orange. Pesquisa Agropecuária Brasileira, Brasília, v.37, p.955-961, 2002. 
MOREIRA-DIAS, J.M.; MOLINA, R.V.; BORDÓN, Y.; GUARDIOLA, J.L.; GARCÍA-LUIS, A. Direct and indirect shoot organogenic pathways in epicotilyl cuttings of Troyer citrange differ in hormone requirements and their response to light. Annals of Botany, Londres, v.85, p.103-110, 2000.

MOREIRA-DIAS, J.M.; MOLINA, R.V.; GUARDIOLA, J.L.; GARCÍA-LUIS, A. Daylength and photon flux density influence the growth regulator effects on morphogenesis in epicotyl segments of Troyer citrange. Scientia Horticulturae, Amsterdam, v.87, p.275-290, 2001.

MOURA, T.L.M.; ALMEIDA, W.A.B.; MENDES, J.M.B.; MOURÃO FILHO, F.A.A. Organogênese in vitro de Citrus em função de concentrações de BAP e seccionamento do explante. Revista Brasileira de Fruticultura, Jaboticabal, v.23, p.240-245, 2001.

MURASHIGE, T.; TUCKER, D.P.H. Growth factor requirement of Citrus tissue culture. In: Chapman, H.D. (Ed.). In: FIRST INTERNATIONAL CITRUS SYMPOSIUM, 1., 1969, Riverside. Proceedings... p. $1155-1161$.

PEÑA, L.; CERVERA, M.; JUÁREZ, J.; NAVARRO, A.; PINA, J.A.; NAVARRO, L. Genetic transformation of lime (Citrus aurantifolia Swing.): factors affecting transformation and regeneration. Plant Cell Reports, Berlin, v.16, p.731-737, 1997.

PÉREZ-MOLPHE-BALCH, E.; OCHOA-ALEJO, $\mathrm{N}$. In vitro plant regeneration of Mexican lime and mandarin by direct organogenesis. HortScience, Alexandria, v.32, p.931-934, 1997.
PHILLIPS, R.C. Invited review: in vitro morphogenesis in plants - recent advances. In Vitro Cellular \& Developmental Biololy - Plant, Columbia, v.40, p.342-45, 2004.

SCHINOR, E.H. Organogênese in vitro e transformação genética em Citrus sp. com o gene da capa proteica e uma sequência conservada antisense do vírus da tristeza dos citros. 2006. 88 f. Tese (Doutorado) - Escola Superior de Agricultura "Luiz de Queiroz”, Universidade de São Paulo, Piracicaba, 2006.

SCHINOR, E.H.; PAOLI, L.G.; AZEVEDO, F.A.; MOURÃO FILHO, F.A.A.; MENDES, B.M.J. Organogênese in vitro a partir de diferentes regiões do epicótilo de Citrus sp. Revista Brasileira de Fruticultura, Jaboticabal, v.28, p.463-466, 2006.

SILVA, R.P.; COSTA, M.A.P.C.; SOUZA, A.S.; ALMEIDA, W.A.B. Regeneração de plantas de laranja-Pera via organogênese in vitro. Pesquisa Agropecuária Brasileira, Brasília, v.40, p.11531159, 2005a.

SILVA, R.P.; MENDES, B.M.J.; MOURÃO FILHO, F.A.A. Indução e cultivo in vitro de gemas adventícias em segmentos de epicótilo de laranja-azeda. Pesquisa Agropecuária Brasileira, Brasília, v.43, p.1331-1337, 2008.

SILVA, R.P.; SOUZA, E.S.; REBOUÇAS, F.S.; ALMEIDA, W.A.B. Otimização de protocolos para regeneração de plantas in vitro de tangerina 'Cleópatra' (Citrus reshni Hort. ex Tan.) Revista Brasileira de Fruticultura, Jaboticabal, v.27, p.484-487, $2005 b$. 